\title{
METAL-CHELATING PROPERTIES, ELECTROCHEMICAL BEHAVIOR, SCAVENGING AND CYTOPROTECTIVE ACTIVITIES OF SIX NATURAL PHENOLICS
}

\author{
Jitka Psotováa*, Jan Lasovskýb, Jaroslav Vičar ${ }^{a}$
}

a Institute of Medical Chemistry and Biochemistry, Faculty of Medicine, Palacký University, Hnèvotínská 3, 77515 Olomouc, Czech Republic, psotova@tunw.upol.cz

b Department of Physical Chemistry, Faculty of Science, Palacký University, Tr. Svobody 26, 77146 Olomouc, Czech Republic

Received: October 28, 2003; Accepted: December 5, 2003

Key words: Phenolic acids / Chelatation / DPPH / Cyclic voltammetry / Lipid peroxidation / Rat mitochondria / Rat erythrocytes / Rat hepatocytes

Chelation, electrochemical, antioxidant and cytoprotective properties of six phenolics - cynarin and caffeic, chlorogenic, ferulic, protocatechuic and rosmarinic acids were studied on the following models: (i) chelation of transition metals, (ii) quenching of the diphenylpicrylhydrazyl radical (DPPH), (iii) determination of half-wave potential, (iv) erythrocytres or mitochondrial membranes damaged by tert-butyl hydroperoxide $(t \mathrm{BH})$ and $(\mathrm{v})$ a primary culture of rat hepatocytes intoxicated by $\mathrm{Cu}(\mathrm{II})$ and $\mathrm{Fe}(\mathrm{III})$ or $t \mathrm{BH}$. All phenolics suppressed cell membrane damage induced by transition metals or $t \mathrm{BH}$. The protectivity correlated with their capacity to bind transition metals, to scavenge DPPH radical and with the value of half-wave potentials. In in vitro assays, the most promising was rosmarinic acid.

\section{INTRODUCTION}

Protocatechuic (PA), ferulic (FA) and caffeic acid (CA) $\left(\mathrm{C}_{6}-\mathrm{C}_{3}\right)$ are secondary metabolites in all higher plant genera ${ }^{1,2}$. Their precursor is phenylalanine with the exception of rosmarinic acid (RA) where one of the two $\mathrm{C}_{6}-\mathrm{C}_{3}$ structural units is derived from tyrosine. In plants, these acids occur mostly as esters, for instance caffeic acid as chlorogenic acid (CHA) and cynarin (CY), or bound to biopolymers. One of the physiological functions of these acids is the protection of plant tissues against the toxic effects of radicals. They represent an important group of dietary phytochemicals. In the literature there is a plethora of data assessing the chemoprotective potential of phenolic acids ${ }^{3}$. However, the results reflect different experimental approaches and methodologies and in some cases they are hard to compare. In this paper, we examine a series of six phenolics (PA, CA, FA, CHA, RA, CY) using methods: evaluation of their chelation activity, scavenging of $\mathrm{HO}$ radical, reduction ability, inhibition of lipid peroxidation, and cytoprotectivity in order to correlate chemoprotective behaviour with structures.

\section{MATERIALS AND METHODS}

\section{Phenolic Acids and Reagents}

Protocatechuic acid (3,4-dihydroxybenzoic acid; PA), trans-ferulic acid (3-(4-hydroxy-3-methoxyphenyl)-2-propenoic acid; FA) chlorogenic acid (3-caffeoylquinic acid; $\mathrm{CHA})$ and quercetin $(\mathrm{QE})$ were obtained from SigmaAldrich (Germany). trans-Caffeic (3-(3,4-dihydroxy- phenyl)-2-propenoic acid; CA) and $(R)-(+)$-rosmarinic (O-caffeoyl-(3,4-dihydroxyphenyl)lactic acid; RA) acids were isolated from Prunella vulgaris ${ }^{4}$. Cynarin (1,5-dicafeoylquinic acid; CY) was kindly donated by Dr. J. Slanina (Brno, Czech Republic), tert-Butyl hydroperoxide $(t \mathrm{BH})$ was from Merck (Germany). Metalcaptase ${ }^{\circledR} 150$ (penicillamin) was from Heyl (Germany), Desferal was from CIBA-GEIGY (Switzerland). All other chemicals used were obtained from Pliva-Lachema (Czech Republic) and Sigma-Aldrich. All were of analytical grade.

\section{Spectrophotometric Equilibrium Measurements}

Interactions of phenolics (PA, CA, FA, CHA, RA and $\mathrm{CY}$ ), the arising complexes with transition metals $(\mathrm{Cu}(\mathrm{II})$ and $\mathrm{Fe}(\mathrm{III}))$, and stoichiometry were studied spectrophotometrically with metal ion concentrations $\left(\mathrm{Cu}\left(\mathrm{ClO}_{4}\right)_{2} \cdot 6 \mathrm{H}_{2} \mathrm{O}, \mathrm{FeCl}_{3}\right) 2 \times 10^{-6}-5 \times 10^{-4} \mathrm{M}$, and ligand concentration of $5 \times 10^{-5} \mathrm{M}$ at $\mathrm{pH}$ 7.4. Phosphate buffer solution $(0.2 \mathrm{M})$ - saline $(0.15 \mathrm{M} \mathrm{NaCl})$ was used in order to match reaction conditions used for cell culture experiments. The composition of the complex was determined from the absorbance/metal ion concentration relationship $A=f\left(c_{\text {Metal }}\right)_{c_{\text {Ligand }}}$.

\section{Scavenging Activity of DPPH Radical}

The antioxidant activity of test compounds was determined on the basis of the scavenging activity of 1,1-diphenyl-2-picrylhydrazyl radical (DPPH) (ref. $\left.{ }^{5}\right)$ Aliquots of $0.75 \mathrm{~mL}$ of a methanolic solution containing test compound $(0.01-0.10 \mathrm{mM})$ were added to $1.5 \mathrm{~mL}$ of methanolic DPPH solution ( $\left.20 \mathrm{mg} . \mathrm{L}^{-1}\right)$. Absorbance at $517 \mathrm{~nm}$ was determined after $5 \mathrm{~min}$, and percent inhi- 
bition activity $\mathrm{IC}_{50}$ values denote the concentration of sample required to scavenge $50 \% \mathrm{DPPH}$ radicals.

\section{Cyclic Voltammetry}

Cyclic voltammetry was carried out with Potentiostat/ Galvanostat Model 273 (EG\&G, Princetown, USA). A three-electrode system with a working and auxiliary electrode of glassy carbon and platinum and a saturated calomel reference electrode (SCE) was used. The test compounds were dissolved to concentrations of $1 \times 10^{-4} \mathrm{M}$ in sodium-phosphate buffer of $\mathrm{pH}$ 7.4. The solutions were purged with Ar and held under constant Ar flux during the electrochemical experiments. The cyclic voltammograms (CV) were recorded at $21 \pm 2{ }^{\circ} \mathrm{C}$. Half-wave potentials $\left(\mathrm{E}_{\mathrm{pa}}\right)$

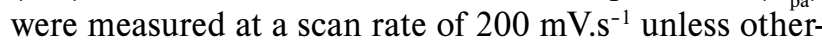
wise indicated. The working electrode was polished with aluminium oxide prior to each electrochemical measurement, because polymeric film formation inactivated the electrode after each scan. Since the surface cannot be reproduced identically each time, the $\mathrm{E}_{\mathrm{pa}}$ value depended on each pre-treatment and for a given compound varied up to $0.05 \mathrm{~V}$ between measurements.

\section{Animals}

Three-month-old male Wistar rats with a body weight of 190-210 $\mathrm{g}$ were used for the preparation of erythrocytes, hepatocytes and liver mitochondria. Rats were supplied with food and water ad libitum and exposed to a $12 \mathrm{~h}$ light-dark cycle.

\section{Haemolysis of Rat Erythrocytes}

Rat erythrocytes were separated from heparinized blood by centrifugation $\left(500 \times \mathrm{g} ; 15 \mathrm{~min} ; 22^{\circ} \mathrm{C}\right)$. Erythrocytes $(10 \% \mathrm{v} / \mathrm{v})$ were incubated in phosphate buffer saline (PBS) buffer ( $\mathrm{pH} 7.4)$ with the test compound $(0.1,0.25$ and $0.5 \mathrm{mM})$ and $t \mathrm{BH}(1.2 \mathrm{mM})$ for $4 \mathrm{~h}$ at $37^{\circ} \mathrm{C}$. After incubation the erythrocyte haemolysis was measured at $540 \mathrm{~nm}^{2}$ as released haemoglobin ${ }^{6}$.

\section{Lipid Peroxidation Assay}

The mitochondrial fraction was prepared from rat liver homogenate and its protein concentration was determined by the Lowry method ${ }^{7}$. Mixtures of mitochondrial suspension $(0.8 \mathrm{~mL} ; 4 \mathrm{mg}$ total protein $/ \mathrm{mL})$ and test compounds dissolved in DMSO $(0.1 \mathrm{~mL} ; 0.1-25.0 \mathrm{mM})$ were incubated in a shaking water bath at $37^{\circ} \mathrm{C}$ and lipid peroxidation was induced by $0.02 \mathrm{~mL} \mathrm{TBH}$, final concentration $1.5 \mathrm{mM}$ (ref. $^{8}$ ) for $1 \mathrm{~h}$. The products of lipid peroxidation (TBARS) were determined by reaction with thiobarbituric acid $^{9}$.

\section{Rat Hepatocyte Culture}

Rat hepatocytes were isolated by two-step collagenase perfusion of liver ${ }^{10}$. The cells were then resuspended in William's medium E, supplemented with glutamine (2 mM), streptomycin $(0.1 \mathrm{~g} / \mathrm{L})$, penicillin $\mathrm{G}(10000 \mathrm{U} /$ $\mathrm{L})$, dexamethasone $(1 \mu \mathrm{M})$ and insulin $(0.1 \mu \mathrm{M})$, and washed by centrifugation $(50 \times g ; 1 \mathrm{~min})$. Using the trypan blue exclusion test, cell viability was $\sim 90 \%$. Cell suspen- sions in medium supplemented with $10 \%$ bovine serum were seeded on collagen type I pre-coated 24-well plates at a density of $1 \times 10^{5}$ cells $/ \mathrm{cm}^{2}$ and incubated at $37^{\circ} \mathrm{C}$ in an atmosphere containing $5 \% \mathrm{CO}_{2}$. The medium was changed for a serum-free one after $3 \mathrm{~h}$. Rat hepatocytes were preincubated for $4 \mathrm{~h}$ with phenolic acids (0.025-1.0 $\mathrm{mM})$, then exposed to toxic concentrations of $20 \mu \mathrm{M}$ $\mathrm{Fe}$ (III) or $\mathrm{Cu}$ (II) for $20 \mathrm{~h}$, respectively. For $t \mathrm{BH}$ intoxication $(0.5 \mathrm{mM}, 90 \mathrm{~min})$, cells were preincubated for $20 \mathrm{~h}$ with test compounds. After the experiment, the culture medium was removed and assayed for extracellular lactate dehydrogenase activity (LDH) and thiobarbituric acid reactive substances (TBARS). The level of intracellular reduced glutathione (GSH) was determined according to Sedlak and Lindsay (1968) (ref. ${ }^{11}$ ).

\section{Statistical Analysis}

Values were expressed as mean \pm s.e.m. Each experiment was performed in triplicate and measured three times. Student $t$-test was used for statistical analysis.

\section{RESULTS}

The interaction of phenolic compounds with $\mathrm{Cu}$ (II), $\mathrm{Fe}$ (III) and stoichiometry of formed complexes was studied spectrophotometrically using molar ratios method at $\mathrm{pH}$ 7.4. Except for FA, all phenolics formed $\mathrm{Cu}$ (II) complexes; apart from PA and FA they formed Fe(II) complexes. As for $\mathrm{Fe}$ (III) complexes, they are formed by RA, CHA, CY. The formation of complexes was manifested by the appearance of an absorption band in the region 308-375 $\mathrm{nm}$. The dependence of absorbance on the concentration of metal ions shows: (i) the composition of the complex depends on the metal/ligand ratio and there are two types of complexes formed with the stoichiometry metal : ligand $1: 1$ and $1: 2$; (ii) complexes of both types are stable. Estimation of the stability constant carried out for a $1: 1$ complex from equimolar solutions $\left(c_{\mathrm{M}} \cong c_{\mathrm{L}}\right)$ considering the difference between the curves of a quantitative and of an actual reaction yields the constants in the range $2 \times 10^{5}-5 \times 10^{6}$ for all ligands and both metals, see Table 1 . After the addition of EDTA to all complexes, the spectra of non-complexed phenolics were restored.

The scavenging of the DPPH radical is a simple model reaction providing relevant information about the ability of acids to scavenge free hydroxyl radicals. The adventitious data are then correlated with their antilipoperoxidative properties in vitro models. However there are conflicting data on phenolic acids in the literature. The order of scavenging effectiveness found here was: CA > $\mathrm{RA}>\mathrm{CY}>\mathrm{CHA}>\mathrm{PA}>\mathrm{FA} \gg \mathrm{QE}$ (Table 2). Statistically significant different scavenging effect of phenolic acids compared to quercetin can be explained by the presence of a carboxyl group rather than by the number and position of phenolic groups. We found similar $\mathrm{IC}_{50}$ for CA and RA. These differ from Chen et al. ${ }^{12}$ who published that RA was significantly better than CA. 
The half-wave oxidation potentials $\left(\mathrm{E}_{\mathrm{pa}}\right)$ provide evidence for reduction properties. Low values imply strong reducing power. The anodic current reflects the concentration of the antioxidant and the number of electrons transferred in the reduction. This can be used for quantification. The low values of anodic potentials for CA, RA, and CHA were determined. They were similar to the value of QE (Table 2).

Phenolics were able to prevent lipid peroxidation of erythrocytes. The protective effect was dose dependent. While at $0.1 \mathrm{mM}$ the most effective acids were PA and $\mathrm{CA}$, at $0.25 \mathrm{mM}$ it was RA and CA which showed the highest efficiency. CY and CHA were least effective over the whole concentration range (Table 3 ).

The results for antilipoperoxidative activity of phenolics on rat mitochondria damaged by $t \mathrm{BH}$ are shown in Table 4. RA was markedly active ( $\mathrm{RA}>\mathrm{CA}>\mathrm{CY}>\mathrm{CHA}>\mathrm{FA}$ $=$ PA).

The cytoprotective effect of phenolic acids was followed on primary rat hepatocyte cultures intoxicated by transition metals, $\mathrm{Cu}(\mathrm{II})$ and $\mathrm{Fe}(\mathrm{III})$, and $t \mathrm{BH}$. The level of TBARS as a parameter of lipid peroxidation damage (Table 5), the level of extracellular LDH as a parameter of cellular damage (Table 6) and of intracellular GSH as a parameter of redox cell status (Table 7) were also measured. Cytoprotective effect of phenolic acids on metal intoxicated hepatocytes was compared with that of therapeutically used metal chelators, desferal and penicillamin. All phenolic acids were able to decrease the level of lipid peroxidation on all three models. On hepatocytes intoxicated by $\mathrm{Fe}(\mathrm{III}), \mathrm{CA}, \mathrm{RA}$ and $\mathrm{CY}(0.5$ and $1.0 \mathrm{mM})$ decreased lipid peroxidation comparably to desferal, but desferal was more effective at lower concentrations $(0.1 \mathrm{mM})$. Phenolic acids protected hepatocytes intoxicated by $\mathrm{Cu}$ (II) better than penicillamin $(\mathrm{RA}>\mathrm{CA}=\mathrm{CHA}=\mathrm{CY}=\mathrm{PA}>\mathrm{FA})$, but CHA and $\mathrm{CY}(1.0 \mathrm{mM})$ stimulated TBARS production. A surprisingly potent protective effect of PA $(1.0 \mathrm{mM})$ was found. On a model of hepatocytes intoxicated by $t \mathrm{BH}$, all tested compounds inhibited the production of TBARS ( $\mathrm{RA}>\mathrm{CA}>\mathrm{CY}=\mathrm{PA}=\mathrm{FA}>\mathrm{CHA})$.

Assessed by the LDH parameter, all phenolics were able to decrease cellular damage on all three models as well (Table 6). Hepatocytes intoxicated by $\mathrm{Fe}$ (III) were protected by phenolic acids in the following order: $\mathrm{CY}>\mathrm{CA}>\mathrm{RA}=\mathrm{CHA}>\mathrm{PA}>\mathrm{FA} . \mathrm{CY}$ and desferal were comparably effective at lower concentrations $(0.1 \mathrm{mM})$. Similarly to TBARS parameter, phenolic acids protected hepatocytes intoxicated by $\mathrm{Cu}$ (II) better than penicillamin $(\mathrm{RA}=\mathrm{CY}=\mathrm{CA}>\mathrm{CHA}>\mathrm{PA}=\mathrm{FA})$. On a model of hepatocytes intoxicated by $t \mathrm{BH}$ all phenolic acids decreased the release of $\mathrm{LDH}$ in the medium $(\mathrm{RA}>\mathrm{CA}>\mathrm{CY}=\mathrm{CHA}>$ PA $>$ FA).

Phenolics were able to eliminate intracellular GSH decrease on all three models, see Table 7. Hepatocytes intoxicated by $\mathrm{Fe}(\mathrm{III})$ were protected by phenolic acids in this order: $\mathrm{CY}>\mathrm{CA}>\mathrm{CHA}>\mathrm{RA}>\mathrm{PA}>\mathrm{FA}$. As with the LDH parameter, CY protected comparably to desferal. In the case of $\mathrm{Cu}$ (II) intoxication, all phenolic acids except for FA protected intracellular GSH level similarly or better than penicillamin $(\mathrm{CY}>\mathrm{RA}=\mathrm{CHA}>\mathrm{CA}=\mathrm{PA}>\mathrm{FA})$. On hepatocytes intoxicated by $t \mathrm{BH}$, phenolic acids eliminated the decrease of GSH $(\mathrm{CHA}>\mathrm{RA}>\mathrm{CY}>\mathrm{CA}>\mathrm{PA}>\mathrm{FA})$.

Table 1. Complexes of phenolic compounds with transition metals.

\begin{tabular}{|c|c|c|c|c|}
\hline \multirow[b]{2}{*}{ Compound } & \multicolumn{4}{|c|}{ Absorption maximum $(\mathrm{nm})$} \\
\hline & Non-complexed & $\mathrm{Cu}(\mathrm{II})$ complex & $\begin{array}{c}\mathrm{Fe}(\mathrm{II}) \text { complex } \\
\text { Metal : Ligand } \\
\text { Stability constant }\end{array}$ & $\mathrm{Fe}(\mathrm{III})$ complex \\
\hline PA & 289 & $\begin{array}{c}308, \text { light yellow } \\
1: 1,1: 2 \\
4.35 \times 10^{6}\end{array}$ & 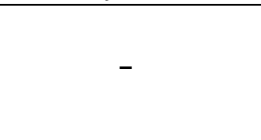 & - \\
\hline $\mathrm{CA}$ & 312 & $\begin{array}{c}\text { 346, colourless } \\
1: 1,1: 2 \\
1.68 \times 10^{6}\end{array}$ & $\begin{array}{c}358, \text { colourless } \\
1: 1,1: 2 \\
-\end{array}$ & - \\
\hline RA & 325 & $\begin{array}{c}372 \text {, light yellow } \\
1: 1,1: 2 \\
2.44 \times 10^{5}\end{array}$ & $\begin{array}{c}354-360, \text { blue } \\
1: 1,1: 2 \\
2.25 \times 10^{5}\end{array}$ & $\begin{array}{c}372, \text { blue } \\
1: 1,1: 2 \\
\quad-\end{array}$ \\
\hline CHA & 324 & $\begin{array}{c}372, \text { light yellow } \\
1: 1,1: 2 \\
6.58 \times 10^{5}\end{array}$ & $\begin{array}{l}372, \text { blue } \\
1: 1,1: 2 \\
6.78 \times 10^{5}\end{array}$ & $\begin{array}{l}375, \text { blue } \\
1: 1,1: 2 \\
8.75 \times 10^{5}\end{array}$ \\
\hline $\mathrm{CY}$ & 325 & $\begin{array}{c}375 \text {, light yellow } \\
1: 1,1: 2 \\
2.35 \times 10^{6}\end{array}$ & $\begin{array}{c}358, \text { blue } \\
1: 1,1: 2 \\
1.84 \times 10^{6}\end{array}$ & $\begin{array}{c}358, \text { blue } \\
1: 1,1: 2 \\
6.35 \times 10^{5}\end{array}$ \\
\hline
\end{tabular}

FA did not display chelating activity. 
Table $2 . \mathrm{IC}_{50}$ values for the scavenging activity and redox potential of phenolic acids.

\begin{tabular}{lrc}
\hline Compound & $\mathrm{IC}_{50}(\mu \mathrm{M})^{\mathrm{a}}$ & $\mathrm{E}_{\mathrm{pa}}(\mathrm{V})$ \\
\hline PA & $8.87 \pm 0.64^{\mathrm{b}}$ & 0.46 \\
$\mathrm{CA}$ & $4.75 \pm 0.25^{\mathrm{b}}$ & 0.10 \\
$\mathrm{FA}$ & $37.10 \pm 2.84^{\mathrm{b}}$ & 0.39 \\
$\mathrm{RA}$ & $5.15 \pm 0.15^{\mathrm{b}}$ & 0.13 \\
$\mathrm{CHA}$ & $6.94 \pm 0.47^{\mathrm{b}}$ & 0.11 \\
$\mathrm{CY}$ & $5.00 \pm 0.09^{\mathrm{b}}$ & 0.33 \\
\hline
\end{tabular}

$\mathrm{IC}_{50}$ and $\mathrm{E}_{\mathrm{pa}}$ values for QE were $66.3 \pm 3.7 \mu \mathrm{M}$ and $0.16 \mathrm{~V}$, respectively.

a $\quad \mathrm{IC}_{50}$ values were determined graphically from dose-activity curves.

b Significantly more active than reference substance quercetin $(\mathrm{p}<0.01)$.

Table 3. Effect of phenolic acids and cynarin on rat erythrocyte haemolysis induced by $t \mathrm{BH}$.

\begin{tabular}{lrcc}
\hline Compound & \multicolumn{5}{c}{$\begin{array}{c}\text { Concentration }(\mathrm{mM}) \\
0.25\end{array}$} \\
& \multicolumn{5}{c}{$\begin{array}{c}0.250 \\
\text { Inhibitory activity (\%) }\end{array}$} \\
\hline PA & $64.3 \pm 4.1$ & $72.0 \pm 6.4$ & $83.2 \pm 7.3$ \\
CA & $55.8 \pm 5.4$ & $84.8 \pm 8.5$ & $86.7 \pm 8.7$ \\
FA & $30.7 \pm 2.2$ & $62.7 \pm 4.8$ & $73.3 \pm 6.4$ \\
RA & $37.1 \pm 2.1$ & $91.4 \pm 9.0$ & $91.7 \pm 9.0$ \\
CHA & $9.4 \pm 0.9$ & $16.5 \pm 1.2$ & $54.5 \pm 3.9$ \\
CY & $10.2 \pm 1.5$ & $17.2 \pm 2.0$ & $56.7 \pm 4.5$ \\
\hline
\end{tabular}

Control value was $92.7 \pm 9.1$ and $t \mathrm{BH}(1.2 \mathrm{mM})$ value was $0.4 \pm 0.0$.

Table 4. Antilipoperoxidative effect of phenolic acids and cynarin on lipoperoxidation of rat mitochondria induced by $t \mathrm{BH}$.

\begin{tabular}{cc}
\hline Compound & $\mathrm{IC}_{50}(\mathrm{mM})$ \\
\hline PA & $>2.0$ \\
CA & $0.59 \pm 0.04$ \\
FA & $>2.0$ \\
RA & $0.09 \pm 0.01$ \\
CHA & $2.37 \pm 0.15$ \\
CY & $1.96 \pm 0.13$ \\
\hline
\end{tabular}


Table 5. Effect of phenolic acids, desferal and penicillamin on extracellular level of TBARS in rat hepatocyte primary cultures intoxicated by $20 \mu \mathrm{M} \mathrm{Fe}(\mathrm{III}), 20 \mu \mathrm{M} \mathrm{Cu}(\mathrm{II})$ and $0.5 \mathrm{mM} t \mathrm{BH}$.

\begin{tabular}{|c|c|c|c|c|}
\hline \multirow{2}{*}{ Compound } & \multirow{2}{*}{$\begin{array}{l}\text { Dose } \\
(\mathrm{mM})\end{array}$} & \multicolumn{3}{|c|}{ Protection (\%) } \\
\hline & & $\mathrm{Fe}(\mathrm{III})$ & $\mathrm{Cu}(\mathrm{II})$ & $t \mathrm{BH}$ \\
\hline \multirow[t]{3}{*}{ PA } & 0.1 & $0.0 \pm 0.9$ & $77.9 \pm 4.7$ & $0.9 \pm 0.1$ \\
\hline & 0.5 & $42.6 \pm 2.1$ & $88.9 \pm 5.6$ & $10.5 \pm 0.9$ \\
\hline & 1.0 & $63.9 \pm 3.4$ & $99.6 \pm 7.2$ & $37.1 \pm 1.7$ \\
\hline \multirow[t]{3}{*}{ CA } & 0.1 & $59.7 \pm 2.8$ & $88.3 \pm 6.7$ & $32.3 \pm 2.4$ \\
\hline & 0.5 & $99.6 \pm 5.8$ & $88.5 \pm 7.0$ & $55.2 \pm 3.4$ \\
\hline & 1.0 & $99.9 \pm 7.0$ & $93.4 \pm 6.5$ & $75.9 \pm 5.1$ \\
\hline \multirow[t]{3}{*}{ FA } & 0.1 & $0.0 \pm 0.7$ & $49.9 \pm 2.4$ & $2.3 \pm 0.4$ \\
\hline & 0.5 & $9.9 \pm 1.2$ & $79.3 \pm 4.1$ & $10.6 \pm 1.1$ \\
\hline & 1.0 & $23.6 \pm 1.8$ & $89.7 \pm 6.8$ & $39.7 \pm 3.1$ \\
\hline \multirow[t]{3}{*}{ RA } & 0.1 & $58.5 \pm 3.1$ & $96.4 \pm 7.2$ & $43.4 \pm 3.2$ \\
\hline & 0.5 & $96.3 \pm 4.9$ & $99.9 \pm 6.7$ & $63.5 \pm 5.2$ \\
\hline & 1.0 & $99.8 \pm 6.4$ & $100.1 \pm 6.0$ & $89.0 \pm 7.6$ \\
\hline \multirow[t]{3}{*}{$\mathrm{CHA}$} & 0.1 & $2.4 \pm 0.6$ & $97.1 \pm 5.4$ & $9.8 \pm 0.8$ \\
\hline & 0.5 & $86.8 \pm 7.2$ & $92.0 \pm 6.1$ & $14.9 \pm 1.6$ \\
\hline & 1.0 & $89.6 \pm 6.3$ & $81.4 \pm 4.5$ & $25.0 \pm 1.9$ \\
\hline \multirow[t]{3}{*}{ CY } & 0.1 & $75.1 \pm 5.4$ & $97.7 \pm 4.9$ & $7.7 \pm 0.7$ \\
\hline & 0.5 & $99.3 \pm 7.8$ & $95.0 \pm 4.2$ & $16.0 \pm 1.3$ \\
\hline & 1.0 & $99.7 \pm 6.4$ & $89.8 \pm 9.3$ & $35.3 \pm 2.6$ \\
\hline \multirow[t]{3}{*}{ DES } & 0.1 & $97.7 \pm 6.2$ & & \\
\hline & 0.5 & $99.9 \pm 7.0$ & & \\
\hline & 1.0 & $96.1 \pm 7.2$ & & \\
\hline \multirow[t]{3}{*}{ PEN } & 0.1 & & $3.7 \pm 0.3$ & \\
\hline & 0.5 & & $9.5 \pm 0.8$ & \\
\hline & 1.0 & & $30.3 \pm 3.0$ & \\
\hline
\end{tabular}

Values are mean \pm s.e.m. of three times repeated experiments.

TBARS control values were for intoxication by: Fe(III) $0.005 \mathrm{pmol} / 10^{6}$ cells $(0.10 \pm 0.03 \%), \mathrm{Cu}(\mathrm{II}) 0.005 \mathrm{nmol} / 10^{6} \mathrm{cells}$ $(0.2 \pm 0.08 \%)$ and $t \mathrm{BH} 0.08 \mathrm{nmol} / 10^{6}$ cells $(2.1 \pm 0.2 \%)$.

TBARS toxicity values were for intoxication by: Fe(III) $5.17 \mathrm{nmol} / 10^{6}$ cells $(100.2 \pm 1.1 \%), \mathrm{Cu}$ (II) $5.36 \mathrm{nmol} / 10^{6} \mathrm{cells}$ $(100.0 \pm 0.8 \%)$ and $t \mathrm{BH} 4.15 \mathrm{nmol} / 10^{6}$ cells $(100.8 \pm 0.3 \%)$.

\section{DISCUSSION}

Phenolic acids are contained in a number of agricultural and medicinal plants. They are respected phytochemicals with prebiotic, antioxidant, chelation and anti-inflammatory effects. Their toxicity is low and they are considered non-toxic. Pharmacologically best characterized is CA with its esters and RA. As for the antioxidant/scavenging activity of these compounds, there are wide ranging reports in the literature which rarely match. On the other hand, chelation effect of these substances, characterized by the efficacy to bind free copper and iron, have not been thoroughly studied so far. Our results show that in in vitro assays, phenolic acids displayed the same or higher cytoprotectivity against the ROS formation than desferal (Fe intoxication) or penicillamin $(\mathrm{Cu}$ intoxication). In the whole concentration range tested $(0.1-1.0 \mathrm{mM})$, the most efficient substances were acids/their esters with a catechol group and a double bond in the side chain. A distinctly superior chelation ef- fect of CA esters (i.e. CHA and CY) compared to CA was found in iron intoxication. In copper intoxication, tested compounds were better protectants than penicillamin. In erythrocytes and mitochondrial membranes damaged by $t \mathrm{BH}, \mathrm{CA}$ and RA were more effective protectants than CHA, CY, PA, and FA. In this assay, the magnitude of the protective effect agreed with the $\mathrm{IC}_{50}$ of the $\mathrm{DPPH}$ quenching and with $\mathrm{E}_{\mathrm{pa}}$ potentials of these substances.

Like many other substances, phenolic acids, too, display a bimodal effect. In the concentration range (0.1-1.0 mM) that we used, the acids behaved as antioxidants with chemoprotective effects. In contrast, $\mathrm{PA}$ at concentrations above $2.5 \mathrm{mM}$ showed in vitro pro-oxidation activity linked to the decrease in reduced glutathione and increase in cellular TBARS ${ }^{13}$. Nakamura et $a l .{ }^{14}$ described hepatotoxic and nephrotoxic effect of PA in mice at doses of $500 \mathrm{mg} / \mathrm{kg}$, linked to decrease in GSH. At higher concentrations of CA and FA, their prooxidation effect on $\mathrm{Cu}^{2+}$-induced LDL oxidation has been described $^{15,16}$ as well. 
Table 6. Effect of phenolic acids, desferal and penicillamin on extracellular level of LDH in primary rat hepatocyte culture intoxicated by $20 \mu \mathrm{M} \mathrm{Fe}(\mathrm{III}), 20 \mu \mathrm{M} \mathrm{Cu}(\mathrm{II})$ and $0.5 \mathrm{mM} t \mathrm{BH}$.

\begin{tabular}{|c|c|c|c|c|}
\hline \multirow[t]{2}{*}{ Compound } & \multirow{2}{*}{$\begin{array}{l}\text { Dose } \\
(\mathrm{mM})\end{array}$} & \multicolumn{3}{|c|}{ Protection (\%) } \\
\hline & & $\mathrm{Fe}(\mathrm{III})$ & $\mathrm{Cu}(\mathrm{II})$ & $t \mathrm{BH}$ \\
\hline \multirow[t]{3}{*}{ PA } & 0.1 & $21.9 \pm 2.1$ & $34.1 \pm 3.2$ & $0.3 \pm 0.3$ \\
\hline & 0.5 & $67.0 \pm 5.6$ & $48.5 \pm 3.9$ & $8.4 \pm 1.2$ \\
\hline & 1.0 & $91.0 \pm 7.3$ & $60.8 \pm 5.5$ & $39.8 \pm 2.9$ \\
\hline \multirow[t]{3}{*}{ CA } & 0.1 & $89.6 \pm 7.3$ & $37.1 \pm 3.2$ & $25.5 \pm 2.4$ \\
\hline & 0.5 & $99.4 \pm 8.4$ & $80.6 \pm 6.8$ & $53.8 \pm 4.3$ \\
\hline & 1.0 & $106.2 \pm 8.6$ & $85.1 \pm 7.6$ & $68.3 \pm 5.7$ \\
\hline \multirow[t]{3}{*}{ FA } & 0.1 & $26.8 \pm 2.1$ & $30.7 \pm 2.4$ & $0.0 \pm 0.2$ \\
\hline & 0.5 & $57.2 \pm 4.3$ & $40.2 \pm 3.6$ & $4.7 \pm 0.6$ \\
\hline & 1.0 & $74.6 \pm 6.3$ & $54.0 \pm 4.3$ & $17.4 \pm 1.8$ \\
\hline \multirow[t]{3}{*}{ RA } & 0.1 & $81.5 \pm 4.3$ & $32.5 \pm 2.9$ & $41.0 \pm 3.8$ \\
\hline & 0.5 & $96.0 \pm 8.3$ & $77.5 \pm 6.8$ & $79.3 \pm 6.5$ \\
\hline & 1.0 & $97.9 \pm 7.8$ & $104.0 \pm 9.9$ & $99.7 \pm 8.7$ \\
\hline \multirow[t]{3}{*}{ CHA } & 0.1 & $78.7 \pm 6.9$ & $41.0 \pm 3.2$ & $28.3 \pm 2.4$ \\
\hline & 0.5 & $103.4 \pm 9.8$ & $61.4 \pm 5.3$ & $38.1 \pm 2.9$ \\
\hline & 1.0 & $112.0 \pm 8.9$ & $88.1 \pm 7.2$ & $53.5 \pm 4.3$ \\
\hline \multirow[t]{3}{*}{$\mathrm{CY}$} & 0.1 & $101.6 \pm 10.1$ & $56.5 \pm 4.3$ & $19.8 \pm 2.4$ \\
\hline & 0.5 & $107.0 \pm 9.8$ & $84.6 \pm 6.8$ & $42.2 \pm 3.1$ \\
\hline & 1.0 & $104.8 \pm 8.9$ & $101.1 \pm 8.3$ & $48.8 \pm 3.9$ \\
\hline \multirow[t]{3}{*}{ DES } & 0.1 & $101.5 \pm 9.8$ & & \\
\hline & 0.5 & $106.4 \pm 9.2$ & & \\
\hline & 1.0 & $101.5 \pm 9.4$ & & \\
\hline \multirow[t]{3}{*}{ PEN } & 0.1 & & $0.0 \pm 0.4$ & \\
\hline & 0.5 & & $26.0 \pm 2.0$ & \\
\hline & 1.0 & & $37.9 \pm 3.4$ & \\
\hline
\end{tabular}

Values are mean \pm s.e.m. of three times repeated experiments.

LDH control values were for intoxication by: $\mathrm{Fe}(\mathrm{III}) 10.34 \pm 0.12 \mathrm{nkat} / 10^{6}$ cells $(25.8 \pm 0.3 \%), \mathrm{Cu}(\mathrm{II}) 9.57 \pm 0.18 \mathrm{nkat} / 10^{6}$ cells $(20.9 \pm 0.4 \%)$ and $t \mathrm{BH} 7.57 \pm 0.76$ nkat $/ 10^{6}$ cells $(14.9 \pm 1.5 \%)$.

LDH toxicity values were for: Fe(III) $40.04 \pm 3.36$ nkat/10 $10^{6}$ cells (100.4 $\pm 8.4 \%$ ), Cu(II) $45.7 \pm 3.5$ nkat/10 cells (100.5 $\left.\pm 7.7 \%\right)$ and $t \mathrm{BH} 50.83 \pm 5.40$ nkat $/ 10^{6}$ cells $(100.4 \pm 10.6 \%)$.

In conclusion it can be said: when evaluating a combined effect of phenolic acids on living organisms, several factors should be considered such as (i) results of in vitro/in vivo studies, (ii) size of the daily dose, (iii) bioavailability, and (iv) potential toxicity of phenolic acid metabolites.

\section{ACKNOWLEDGEMENT}

Financial support by the Ministry of Education, Youth and Sport (MSM 151100003) is gratefully acknowledged.

\section{REFERENCES}

1. Harbore JB. Methods in plant biochemistry. Plant phenolics (Volume 1) Academic Press, London, 1989.

2. Herbert RB. (1989) The biosynthesis of secondary metabolites. Chapman \& Hall, London. P. 96-104.

3. Surh Y-J. (2003) Cancer chemoprevention with dietary phytochemicals. Nature reviews. Cancer. 3, 768-780.
4. Psotová J, Kolář M, Soušek J, Švagera Z, Vičar J, Ulrichová J. (2003) Biological activities of Prunella vulgaris extract. Phytother Res 17, 1082-1087.

5. Deby C, Margotteaux G. (1970) Relationship between essential fatty acids and tissue antioxidant levels in mice. C R Seances Soc Biol Fil 164, 2675-2681.

6. Haraguchi H, Saito T, Okamura N, Yagi A. (1995) Inhibition of lipid peroxidation and superoxide generation by diterpenoids from Rosmarinus officinalis. Planta Med 61, 333-336.

7. Lowry OH, Rosebrough NJ, Farr AL, Randall AJ. (1951) Protein measurement with folin phenol reagent. J Biol Chem 193, 265-275.

8. Mathiesen L, Malterud KE, Sund RB. (1995) Antioxidant activity of fruit exudate and C-methylated dihydrochalcones from Myrica gale. Planta Med 61, 515-518.

9. Buege JA, Aust SD. (1978) Microsomal lipid peroxidation. Methods Enzymol. 52, 302-310.

10. Moldeus P, Högberrg J, Orrenius S. (1978) Isolation and use of liver cells. Methods Enzymol. 52, 60-71.

11. Sedlak J, Lindsay RH. (1968) Estimation of total, protein-bound, and nonprotein sulfhydryl groups in tissue with Ellman's reagent. Anal Biochem 25, 192-205.

12. Chen JH, Ho CT. (1997) Antioxidant activities of caffeic acid and its related hydroxycinnamic acids compounds. J Agric Food Chem $45,2374-2378$. 

and cytoprotective activities of six natural phenolics

Table 7. Effect of phenolic acids, desferal and penicillamin on GSH level in primary rat hepatocyte culture intoxicated by $20 \mathrm{mM} \mathrm{Fe}(\mathrm{III}), 20 \mathrm{mM} \mathrm{Cu}(\mathrm{II})$ and $0.5 \mathrm{mM} t \mathrm{BH}$.

\begin{tabular}{|c|c|c|c|c|}
\hline \multirow[t]{2}{*}{ Compound } & \multirow{2}{*}{$\begin{array}{c}\text { Dose } \\
(\mathrm{mM})\end{array}$} & \multicolumn{3}{|c|}{ Protection (\%) } \\
\hline & & $\mathrm{Fe}(\mathrm{III})$ & $\mathrm{Cu}(\mathrm{II})$ & $t \mathrm{BH}$ \\
\hline \multirow[t]{3}{*}{ PA } & 0.1 & $0.2 \pm 0.1$ & $0.6 \pm 0.3$ & $2.0 \pm 0.3$ \\
\hline & 0.5 & $64.9 \pm 4.4$ & $13.2 \pm 1.1$ & $5.9 \pm 0.5$ \\
\hline & 1.0 & $66.4 \pm 6.3$ & $16.2 \pm 1.5$ & $14.8 \pm 1.9$ \\
\hline \multirow[t]{3}{*}{$\mathrm{CA}$} & 0.1 & $95.3 \pm 8.3$ & $0.9 \pm 1.2$ & $3.9 \pm 1.4$ \\
\hline & 0.5 & $100.2 \pm 8.5$ & $12.1 \pm 1.0$ & $16.7 \pm 1.1$ \\
\hline & 1.0 & $112.8 \pm 8.6$ & $10.8 \pm 1.6$ & $28.5 \pm 2.7$ \\
\hline \multirow[t]{3}{*}{ FA } & 0.1 & $0.1 \pm 1.1$ & $0.5 \pm 1.4$ & $0.2 \pm 0.2$ \\
\hline & 0.5 & $11.5 \pm 1.1$ & $6.8 \pm 0.9$ & $0.8 \pm 0.8$ \\
\hline & 1.0 & $9.1 \pm 1.3$ & $3.5 \pm 0.6$ & $2.9 \pm 0.8$ \\
\hline \multirow[t]{3}{*}{ RA } & 0.1 & $67.3 \pm 5.3$ & $21.1 \pm 2.3$ & $8.1 \pm 0.8$ \\
\hline & 0.5 & $82.9 \pm 4.6$ & $34.9 \pm 2.3$ & $24.8 \pm 2.1$ \\
\hline & 1.0 & $75.9 \pm 6.8$ & $68.2 \pm 5.8$ & $49.9 \pm 3.7$ \\
\hline \multirow[t]{3}{*}{ CHA } & 0.1 & $33.6 \pm 4.9$ & $22.9 \pm 2.9$ & $6.7 \pm 1.4$ \\
\hline & 0.5 & $108.9 \pm 7.9$ & $25.2 \pm 2.1$ & $15.9 \pm 1.3$ \\
\hline & 1.0 & $94.7 \pm 8.9$ & $80.8 \pm 7.2$ & $51.35 \pm 3.3$ \\
\hline \multirow[t]{3}{*}{$\mathrm{CY}$} & 0.1 & $95.6 \pm 10.1$ & $42.5 \pm 4.3$ & $8.2 \pm 1.4$ \\
\hline & 0.5 & $100.9 \pm 6.6$ & $56.5 \pm 5.4$ & $18.2 \pm 1.2$ \\
\hline & 1.0 & $101.8 \pm 8.9$ & $78.4 \pm 7.3$ & $45.8 \pm 3.9$ \\
\hline \multirow[t]{3}{*}{ DES } & 0.1 & $101.5 \pm 9.8$ & & \\
\hline & 0.5 & $104.5 \pm 8.5$ & & \\
\hline & 1.0 & $101.5 \pm 9.4$ & & \\
\hline \multirow[t]{3}{*}{ PEN } & 0.1 & & $7.7 \pm 1.4$ & \\
\hline & 0.5 & & $9.4 \pm 1.3$ & \\
\hline & 1.0 & & $3.9 \pm 2.4$ & \\
\hline
\end{tabular}

Values are mean \pm s.e.m. of three times repeated experiments.

GSH control values were for: $\mathrm{Fe}$ (III) $40.1 \pm 2.6 \mathrm{nmol} / 10^{6}$ cells (100.0 $\pm 6.4 \%$ ), $\mathrm{Cu}$ (II) $42.4 \pm 2.5 \mathrm{nmol} / 10^{6}$ cells $(100.0 \pm$ $5.9 \%)$ and $t \mathrm{BH} 41.8 \pm 3.0 \mathrm{nmol} / 10^{6}$ cells $(100.3 \pm 7.2 \%)$.

GSH toxicity values were for: $\mathrm{Fe}(\mathrm{III}) 4.2 \pm 0.3 \mathrm{nmol} / 10^{6}$ cells ( $10.4 \pm 0.8 \%$, $\mathrm{Cu}$ (II) $10.5 \pm 0.8 \mathrm{nmol} / 10^{6}$ cells $(26.1 \pm 1.9 \%)$ and $t \mathrm{BH} 20.4 \pm 2.1 \mathrm{nmol} / 10^{6}$ cells $(50.9 \pm 5.3 \%)$.

13. Babich H, Sedletcaia A, Kenigsberg B. (2002) In vitro cytotoxicity of protocatechuic acid to cultured human cells from oral tissue: Involvement in oxidative stress. Pharmacol Toxicol 91, 245-253.

14. Nakamura Y, Torikai K, Ohigashi H. (2001) Toxic dose of a simple phenolic antioxidant, protocatechuic acid, attenuates the glutathione level in ICR mouse liver and kidney. J Agric Food Chem 49, 5674-5678.
15. Yamanaka N, Oda O, Nagao S. (1997) Prooxidant activity of caffeic acid, dietary non-flavonoid phenolic acid, on $\mathrm{Cu}^{2+}$-induced low density lipoprotein oxidation. FEBS Letters 405, 186-190.

16. Bourne LC, Rice Evans CA. (1997) The effect of the phenolic antioxidant ferulic acid on the oxidation of low density lipoprotein depends on the pro-oxidant used. Free Rad Res 27, 337-344. 